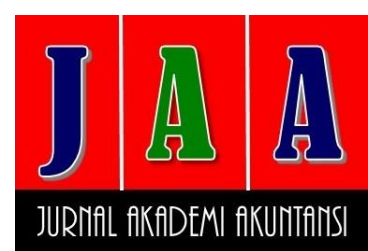

Website:

ejournal.umm.ac.id/index.php/jaa

Afiliasi:

${ }^{1}$ Fakultas Ekonomi dan Bisnis, Universitas Muhammadiyah Malang, Malang, Indonesia

*Correspondence:

Sriwibawani@umm.ac.id

DOI: $\underline{10.22219 / j a a . v 3 i 2.13943}$

Sitasi:

Astuti, S.W.W. (2021). Persepsi

Mahasiswa Terhadap Kesyariahan

Produk Pegadaian Syariah. Jurnal

Akademi Akuntansi, 4(1), 129-137.

Proses Artikel

Diajukan:

16 Maret 2021

Direviu:

20 Maret 2021

Direvisi:

20 Mei 2021

Diterima:

29 Mei 2021

Diterbitkan:

31 Mei 2021

\author{
Alamat Kantor: \\ Jurusan Akuntansi Universitas \\ Muhammadiyah Malang \\ Gedung Kuliah Bersama 2 \\ Lantai 3. \\ Jalan Raya Tlogomas 246, \\ Malang, Jawa Timur, \\ Indonesia
}

P-ISSN: 2715-1964

E-ISSN: 2654-8321
Tipe Artikel: Paper Penelitian

\section{PERSEPSI MAHASISWA TERHADAP KESYARIAHAN PRODUK PEGADAIAN SYARIAH}

Sri Wibawani Wahyuning Astuti ${ }^{1 *}$

\section{ABSTRACT}

The purpose of this study is to explain students' perceptions of LKS products (in this study, PT Pegadaian Syariah) and students' interest in using LKS services after having an adequate understanding of Fiqh Muamalah in Islam. This study was followed by accounting students who took muamalah fiqh courses. In this study, qualitative descriptive analysis techniques were used with primary data through a list of open questions, so that respondents were free to answer research questions. . The results of this study are students' perceptions of Sharia Pawnshop products are definitely in accordance with sharia provisions, namely the provisions of the OJK and DSN MUI fatwas, although they did not conduct a thorough study of the application of each Sharia Pawnshop product and its contracts and pillars. customers from LKS and have never received socialization related to LKS and the products offered and After understanding the importance of sharia muamalah, it turns out that the majority are not interested in using LKS services at this time, because they feel they do not need.

KEYWORDS: LKS; Fiqh Muamalah; Sharia Pawnshop.

\section{ABSTRAK}

Tujuan penelitian ini adalah untuk menjelaskan persepsi mahasiswa terhadap produk LKS (dalam penelitian kali ini adalah PT Pegadaian Syariah) dan minat mahasiswa untuk memanfaatkan jasa LKS setelah memiliki pemahaman yang memadai terhadap Fiqih Muamalah dalam Islam. Penelitian ini diikuti oleh mahasiswa akuntansi yang menempuh mata kuliah fiqh muamalah. Dalam penelitian ini digunakan teknik analisis deskriptif kualitatif dengan data primer melalui daftar pertanyaan terbuka, sehingga responden leluasa dalam menjawab pertanyaan-pertanyaan penelitian. Hasil dari penelitian ini adalah Persepsi mahasiswa tentang produk Pegadaian Syariah adalah pasti sesuai dengan ketentuan syariah, yaitu ketentuan OJK dan fatwa DSN MUI, meskipun tidak melakukan kajian yang seksama terhadap penerapan masingmasing produk Pegadaian Syariah beserta akad dan rukunnya, Sebagian besar responden bukan merupakan nasabah dari LKS dan tidak pernah mendapatkan sosialisasi terkait LKS dan produkproduk yang ditawarkan dan Setelah memahami pentingnya muamalah syariah, ternyata mayoritas belum berminat untuk memanfaatkan jasa LKS pada saat ini, karena merasa belum memerlukan.

KATA KUNCI: LKS; Fiqih Muamalah; Pegadaian Syariah. 


\section{PENDAHULUAN}

Perjalanan keuangan syariah telah berlangsung lebih dari dua dekade, yang ditandai dengan berdirinya Bank Muamalat pada tahun 1991 sebagai Bank syariah pertama di Indonesia. Saat ini keuangan syariah telah berkembang dan membuahkan beberapa prestasi, baik dalam produk dan layanan maupun infrastruktur yang mendukung keuangan syariah. Bahkan Indonesia menempati sepuluh besar Negara yang memiliki indeks keuangan syariah terbesar di dunia. Namun demikian, pertumbuhan keuangan syariah masih belum dapat mengimbangi pertumbuhan keuangan konvensional. Hal ini dapat dilihat dari market share keuangan syariah yang secara keseluruhan masih di bawah 5\% (www.ojk.go.id).

Ditinjau dari jenis produk syariah, hingga akhir Desember 2016 terdapat beberapa produk syariah yang berkembang di atas 5\%, diantaranya aset bank syariah yang sebesar 5,33\% dari seluruh aset perbankan; sukuk Negara yang mencapai $14,82 \%$ dari total surat berharga yang beredar, lembaga pembiayaan syariah sebesar $7,24 \%$ dari total pembiayaan, lembaga jasa keuangan syariah khusus sebesar sebesar 9,93\%, dan lembaga keuangan mikro syariah sebesar 22,26\%. Sedang produk syariah yang pangsa pasarnya masih di bawah 5\% diantaranya sukuk korporasi yang beredar sebesar 3,99\% dari seluruh nilai sukuk dan obligasi korporasi, nilai bersih aset reksa dana syariah sebesar $4,40 \%$ dari seluruh nilai aset bersih reksa dana, dan asuransi syariah sebesar 3,44\% (www.ojk.go.id). Hal ini menunjukkan bahwa keuangan syariah Indonesia masih perlu dikembangkan sehingga dapat mengimbangi pertumbuhan keuangan konvensional atau bahkan menjadi yang lebih dominan, mengingat Indonesia adalah negara dengan penduduk mayoritas Muslim yang terbesar di dunia.

Perkembangan lembaga keuangan syariah (LKS) yang relatif stagnan menimbulkan tanda tanya, mengingat produk-produk syariah juga semakin berkembang dan beragam. Di samping itu, mayoritas penduduk Indonesia beragama Islam dan sebagian diantaranya sudah familiar terhadap lembaga keuangan dan bahkan telah memanfaatkan jasanya. Dengan demikian, nasabah potensial LKS seharusnya relatif besar. Hal ini semestinya juga berdampak pada pertumbuhan LKS yang signifikan. Realitanya jauh panggang dari api, sebagaimana penjelasan OJK (Otoritas Jasa Keuangan) di atas. Hal ini menimbulkan tanda tanya, diantaranya apakah keberadaan LKS beserta produk-produknya belum tersosialisasi dengan baik, apakah produk-produk LKS kurang menimbulkan daya tarik bagi nasabah potensial sehingga enggan memanfaatkan jasa LKS, bagaimana pemahaman nasabah potensial LKS (utamanya mahasiswa) terhadap kaidah bermuamalah dalam Islam, dan bagaimana minat mahasiswa terhadap LKS (khususnya produk Pegadaian Syariah) setelah memiliki pemahaman yang cukup memadai. Karenanya, responden yang dijadikan sampel dalam penelitian ini adalah mahasiswa yang telah menempuh mata kuliah Fiqih Muamalah di Universitas Muhammadiyah Malang. Dengan pemahaman yang memadai terhadap Fiqih Muamalah, diharapkan mereka memiliki pemahaman yang cukup memadai terhadap kaidah bermuamalah dalam Islam.

Tujuan Penelitian ini dimaksudkan untuk menjelaskan persepsi mahasiswa terhadap produk LKS (dalam penelitian kali ini adalah PT Pegadaian Syariah) dan minat mahasiswa untuk memanfaatkan jasa LKS setelah memiliki pemahaman yang memadai terhadap Fiqih Muamalah dalam Islam. Penelitian ini diharapkan dapat memberikan kontribusi bagi institusi Perguruan Tinggi (PT) terkait pemahaman mahasiswa terhadap Fiqih Muamalah dan minat mahasiswa untuk melakukan analisis yang seksama terhadap kesyariahan produk LKS, serta kontribusi terhadap pembenahan model perkuliahan dan kurikulum. Penelitian 
ini juga diharapkan memberikan kontribusi bagi LKS terkait dengan pemahaman nasabah potensial terhadap produk-produk LKS (baca: PT Pegadaian Syariah).

\section{TINJAUAN LITERATUR DAB PERUMUSAN HIPOTESIS}

Dalam pandangan Islam, kegiatan ekonomi yang sesuai dan dianjurkan adalah melalui kegiatan bisnis dan investasi. Beberapa perintah dalam dua hal tersebut telah disampaikan dalam Al-Qur'an dan juga Sunah Rasulullah SAW. Dari dua pegangan hidup umat manusia tersebut dapat dilihat bahwa sistem ekonomi yang dikembangkan oleh Islam memiliki tujuan untuk mewujudkan tingkat pertumbuhan ekonomi umat manusia dalam jangka panjang dan juga dalam rangka memaksimalkan tingkat kesejahteraan umat manusia (Mensani dan Dzikra, 2017).

Sistem keuangan Islam merupakan bagian dari sistem ekonomi yang mengemban amanat yang sama dengan apa yang diharapkan terwujud dalam konsep sistem ekonomi Islam. Sistem ekonomi Islam tidak terlepas dari Bank dan lembaga keuangan. Lembaga keuangan merupakan suatu identitas di dalam sistem ekonomi dan merupakan instrumen yang menerapkan aturan-aturan dalam sistem ekonomi itu sendiri (Mensani dan Dzikra, 2017). Di tengah perlambatan ekonomi global yang memengaruhi pasar keuangan domestik, Otoritas Jasa Keuangan (OJK) melansir masih banyak sektor keuangan yang berhasil mencatat pertumbuhan sampai paruh pertama tahun 2014. Salah satunya, yakni sektor keuangan syariah (Anggraini, 2015).

Berdasarkan data Perkembangan Keuangan Syariah, total aset industri asuransi syariah pada paruh pertama 2014 mencapai Rp 19,26 triliun atau meningkat 15\% dibandingkan akhir tahun sebelumnya, yakni Rp 16,66 triliun. Sementara, aset dana kelolaan reksa dana berprinsip syariah tumbuh dari Rp 9,43 triliun pada akhir tahun 2013 menjadi Rp 9,51 triliun per Juli 2014. Demikian juga industri perbankan syariah juga menunjukkan peningkatan kinerja dengan pertumbuhan 3,4\% atau menjadi sebesar Rp 250,55 triliun sampai Mei 2014. Aset saham syariah juga tercatat naik 15,5\%, yaitu dari Rp 2.557 triliun pada akhir tahun lalu menjadi sebesar Rp 2.955 triliun hingga Juli 2014. Di samping itu, sukuk negara juga meningkat 5,7\% menjadi Rp 179,10 triliun. Peningkatan aset jenis ini sekaligus menggemukkan market share sukuk negara menjadi 9,83\%. Angka ini jauh lebih besar ketimbang market share sukuk korporasi yang hanya berkisar 3,17\% (Anggraini, 2015).

Perkembangan lembaga keuangan syariah menunjukkan peluang bisnis yang menggiurkan. Sejumlah bank asing di Indonesia, seperti Citibank dan HSBC, bahkan bersiap menyambut penerbitan sukuk dengan membuka unit usaha syariah. Sementara itu sejumlah investor dari negara Teluk juga tengah bersiap membeli bank-bank di Indonesia untuk dikonversi menjadi bank syariah. Kriteria bank yang dipilih umumnya beraset relatif kecil, antara Rp 500 miliar dan Rp 2 triliun. Setelah dikonversi, bank-bank tersebut diupayakan melakukan sindikasi pembiayaan proyek besar, melibatkan lembaga keuangan global ( $\underline{\text { Anggraini, 2015)}}$. Dari sisi nasabah, Menzari dan Dzikra (2017) mengungkapkan bahwa banyak nasabah lembaga keuangan syariah (LKS) yang berasal dari non muslim merupakan pemakai atau pelangggan lembaga keuangan berbasis syariah, atau bank syariah. Fenomena tersebut seharusnya menjadi dorongan untuk umat muslim agar lebih memanfaatkan lembaga

JAA keuangan syariah dalam kehidupan dan kegiatan ekonominya.

4.1 Pandangan masyarakat mengenai LKS dipengaruhi oleh pemahaman dan pengetahuan mereka tentang LKS. Manakala pengetahuan tentang bank syariah rendah maka dalam memandang bank syariah pastinya rendah pula. Pada umumnya masyarakat sudah mengetahui apa itu LKS, tetapi mereka tidak mengetahui produk-produk yang ditawarkan 
oleh LKS, sehingga kurang berminat untuk menggunakan jasa LKS karena menganggap bahwa fasilitas penunjang yang diberikan masih kalah dengan fasilitas yang ditawarkan oleh bank konvensional, kecuali orang yang memiliki keinginan kuat menabung pada bank syariah dikarenakan menghindari unsur riba. Anggraini (2015) mengindikasi bahwa produk perbankan syariah yang paling banyak diikuti nasabah adalah wadiah sebesar $52 \%$. Pada dasarnya nasabah tidak mengetahui bahwa produk yang mereka ikuti adalah akad wadiah, mereka hanya mengetahui bahwa mereka membuka tabungan di perbankan syariah dengan pembagian keuntungan bagi hasil, bukan bunga. Sedangkan nasabah yang lainnya sebesar $25 \%$ mengikuti produk deposito mudharabah.

\section{METODE}

Jenis Penelitian ini merupakan penelitian kualitatif karena menyiratkan penekanan pada proses dan makna yang tidak dikaji secara ketat dan terukur dari sisi kuantitas, intensitas, atau frekuensinya. Sebaliknya, penelitian ini menekankan pada sifat realitas yang terbangun secara sosial, hubungan antara peneliti dengan subjek yang diteliti, dan tekanan situasi yang membentuk penyelidikan yang sarat-nilai. Peneliti berupaya mencari jawaban atas pertanyaan-pertanyaan yang menyoroti cara munculnya pengalaman sosial sekaligus perolehan maknanya dalam upaya menemukan makna persepsi mahasiswa terhadap produk LKS, dalam hal ini PT Pegadaian Syariah.

Metode kualitatif digunakan dalam penelitian ini karena lebih mudah menyesuaikan manakala berhadapan dengan realitas ganda di lapangan, penelitian ini menyajikan secara langsung hakikat hubungan antara peneliti dan para responden, dan metode kualitatif lebih peka dan lebih bisa menyesuaikan diri dengan kemungkinan perubahan nilai yang dihadapi.

Dalam penelitian ini digunakan teknik analisis deskriptif kualitatif dengan data primer melalui daftar pertanyaan terbuka, sehingga responden leluasa dalam menjawab pertanyaanpertanyaan penelitian. Beberapa hal yang ditanyakan antara lain:

1. Apakah mahasiswa (kelas Fiqih Muamalah) pernah mendapatkan sosialisasi terkait produk LKS (dalam hal ini PT Pegadaian Syariah).

2. Bagaimana bentuk sosialisasi yang diterima oleh mahasiswa (bilamana pernah mendapatkan sosialisasi).

3. Faktor-faktor apakah yang menyebabkan mahasiswa belum memanfaatkan jasa LKS.

4. Bagaimana pemahaman mahasiswa terhadap produk-produk LKS jika ditinjau dari:

a. Apa sajakah jenis-jenis akad LKS?

b. Bagaiamana kesesuaian produk LKS dengan rukun syariah dan syarat rukun.

c. Bagaimana kesesuaian jenis-jenis akad LKS dengan fatwa DSN MUI, PSAK Syariah, atau literatur syariah

5. Apakah jenis-jenis akad LKS telah terbebas dari hal-hal yang dilarang dalam perniagaan, yaitu:

a. Maysir (tanpa akad/melalui permainan).

b. Gharar (memakai akad namun tidak jelas).

c. Riba (tambahan yang mendhalimi).

d. Bathil (usaha-usaha maksiat).

e. Bai'al Mudhthar (harga yang dimainkan akibat emergency/eksploitasi).

f. Ikrah (harga dimainka dengan tekanan/paksaan).

g. Ghabn (over pricing).

h. Najash (permainan harga melalui berpura-pura menawar).

i. Ihtikar (permainan harga dengan cara menimbun). 
j. Ghish (menyembunyikan informasi tentang barang/jasa).

k. Tadlis (mengambil keuntungan dengan cara mencampur aduk).

6. Bilamana ada akad-akad yang mengandung hal-hal yang dilarang dalam perniagaan (sebagaimana dijelaskan di atas), mohon dijelaskan jenis akad dan alasannya.

7. Berdasarkan pemahaman mahasiswa setelah menempuh kuliah fiqih muamalah dan setelah mendapatkan sosialisasi dari lembaga keuangan syariah, perlu ditanyakan lebih lanjut apakah mahasiswa berminat memanfaatkan jasa LKS.

8. Selanjutnya, bagi mahasiswa yang berminat (lanjutan dari pertanyaan ke 7) memanfaatkan jasa LKS, maka ditanyakan lebih lanjut apakah jenis-jenis akad apa saja yang diminati beserta penjelasannya.

9. Sementara bagi mahasiswa yang tidak berminat memanfaatkan jasa lembaga keuangan syariah, maka ditanyakan lebih lanjut alasannya.

Penelitian ini juga menggunakan pisau analisis fenomenologi untuk memahami fenomena dan mengungkapkan makna di balik fenomena yang tampak. Fenomenologi (phenomenology) berasal dari bahasa Yunani phainomai yang artinya "menampak". Phaenomenon (fenomena) mengandung makna "yang menampak". Dalam artian, bukanlah dirinya yang tampak secara kasat mata, melainkan realitas yang disadari dan masuk dalam pemahaman manusia. Dalam hal ini terdapat suatu objek yang terkait dengan kesadaran, sementara fenomena berada di depan kesadaran dan disajikan dengan kesadaran. Fenomenologi merefleksikan pengalaman langsung manusia, sepanjang pengalaman tersebut secara intensif berhubungan dengan suatu objek. Dengan kata lain, fenomenologi merupakan studi tentang fenomena yang tampak di depan kita dan bagaimana penampakannya. Dalam The Oxford English Dictionary dinyatakan bahwa fenomenologi adalah a) the science of phenomena as distinct from being (ontology), dan b) division of any science which decribes and classifies its phenomena.

Fenomenologi mampu mengungkap objek secara meyakinkan, meskipun objek tersebut berupa objek kognitif maupun tindakan ataupun ucapan, karena segala sesuatu yang dilakukan oleh individu selalu melibatkan mental (Collins, 1997). Merujuk Wirawan (2012), peneliti menggunakan metode fenomenologi untuk memahami makna subjektif manusia yang diatributkan pada tindakan-tindakannya dan sebab-sebab objektif serta konsekuensi dari tindakannya tersebut. Peneliti berupaya menafsirkan (memaknai) pemahaman informan terhadap fenomena yang muncul dalam kesadarannya, serta fenomena yang dialami oleh informan dan dianggap sebagai suatu entitas (sesuatu yang ada dalam dunia). Peneliti tidak bermaksud untuk mencari pendapat benar atau salah dari informan, melainkan berupaya 'mereduksi' kesadaran informan dalam memahami fenomena tersebut

\section{HASIL DAN PEMBAHASAN}

Penelitian ini dilakukan pada mahasiswa yang menempuh mata kuliah Fiqih Muamalah. Situs penelitian meliputi dua kelas Fiqih Muamalah pada Program Studi Akuntansi Fakultas Ekonomi dan Bisnis Universitas Muhammadiyah Malang. Pada awal perkuliahan mahasiswa diberi silabi kuliah dan dijelaskan bahwa selama periode perkuliahan akan diberikan juga beberapa penugasan survei (disertai kisi-kisi pertanyaan yang perlu diajukan), diantaranya adalah mengkaji bagaimana kemungkinan mengubah transaksi yang terjadi pada Koperasi konvensional menjadi syariah dan bagaimana tingkat kesyariahan produk-produk JAA LKS (Lembaga Keuangan Syariah), yang meliputi Koperasi, Perbankan, dan Pegadaian 4.1 Syariah. Selama masa perkuliahan, baik pada saat kuliah maupun di luar jadwal kuliah, mahasiswa diberikan kesempatan untuk berkonsultasi pada Dosen pengampu terkait 
penugasan tersebut. Dalam penelitian kali ini yang hendak diungkapkan adalah penugasan yang terkait dengan kesyariahan produk PT Pegadaian Syariah.

Jumlah responden mahasiswa yang aktif mengikuti perkuliahan Fiqih Muamalah sebanyak 88 responden. Dari jumlah tersebut ternyata ada beberapa yang jawabannya ditulis tangan dan kurang jelas serta ada beberapa responden yang tidak memberikan jawaban sehingga tidak dianalisis lebih lanjut. Dalam hal ini ada sejumlah 74 jawaban responden yang diolah dan dianalisis lebih lanjut. Dalam penugasan survei mahasiswa diberikan keleluasaan waktu untuk menyelesaikan dan melaporkan sampai akhir semester. Terkait model perkuliahan, mahasiswa diberikan opsi apakah menghendaki model perkuliahan tutorial, diskusi, atau perpaduan antara tutorial dan diskusi. Dalam hal ini mahasiswa bersepakat untuk memilih perpaduan model perkuliahan tutorial dan diskusi. Dalam rangka menjadikan mahasiswa lebih siap dalam diskusi maka di awal perkuliahan diberikan materi perkuliahan lengkap berupa e-book dan ppt (power point) Fiqih Muamalah selain ppt per materi pada saat kuliah tutorial dan diskusi (ppt dari kelompok yang presentasi). Di samping itu, kelas dibagi dalam 10 kelompok dan setiap kelompok ditugasi untuk mengumpulkan beberapa fatwa dari DSN MUI (Dewan Standar Nasional Majelis Ulama Indonesia) dengan pembagian tugas diserahkan pada Ketua Tingkat. Selanjutnya, mereka diminta saling berbagi dan mempelajari fatwa-fatwa yang diperoleh sehingga semua mahasiswa memiliki seluruh fatwa yang telah diterbitkan oleh DSN MUI tersebut. Di samping fatwa DSN MUI, kepada mahasiswa juga diberikan PSAK (Pernyataan Standar Akuntansi Keuangan) yang terkait Syariah. Permasalahan yang timbul adalah terjadinya pandemik Covid 19 menjelang batas akhir pengumpulan tugas, sehingga untuk mahasiswa yang belum sempat melakukan survei ke LKS diperkenankan untuk mencari informasi dengan tidak bertatap muka secara langsung, tetapi melalui telepon, internet, dan sarana/prasarana lainnya yang memungkinkan.

Berdasarkan jawaban responden dapat dipetakan realitas persepsi mahasiswa terhadap produk Pegadaian Syariah. Dalam hal ini responden sebagian besar melakukan survei pada kantor Pegadaian yang tersebar di berbagai pelosok tanah air, diantaranya Malang, Surabaya, Mojokerto, Madiun, Jombang, Kediri, Jakarta, Tolitoli, Bima, Mataram, Paser, Pontianak, Banjarmasin, Tarakan, Palangka Raya, Sampit, Medan, Kendari, dan sebagainya. Di samping produk standar yang ditawarkan oleh LKS (PT Pegadaian Syariah) seperti Rahn, Arrum Haji, dan Tabungan Emas, di beberapa daerah terdapat beberapa produk berbeda yang ditawarkan dan nampaknya disesuaikan dengan kebutuhan masyarakat dan pangsa pasar di daerah tersebut.

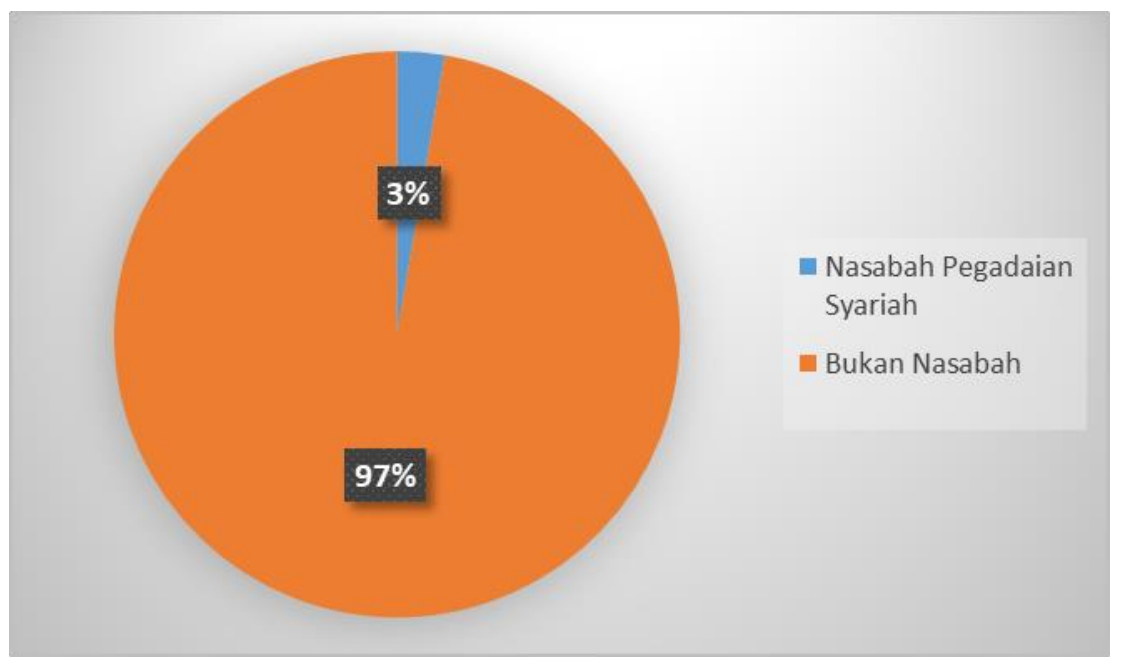


Berdasarkan hasil analisis data diketahui bahwa sebagian besar responden 72 responden atau 97\%) bukan merupakan nasabah dari LKS dan tidak pernah mendapatkan sosialisasi terkait LKS dan produk-produk yang ditawarkan. Hanya dua (2) responden atau sebesar 3 $\%$ yang merupakan nasabah dari LKS (dimana salah satunya bukan nasabah langsung LKS, melainkan orang tuanya). Sebagian besar (88\%) responden juga tidak pernah mendapatkan sosialisasi terkait LKS dan produk-produknya. Dalam hal ini hanya 9 responden (12\%) yang pernah mendapatkan sosialisasi terkait LKS, itupun setelah datang ke kantor perwakilan LKS untuk minta informasi atau kebetulan melihat ketika jalan-jalan ke mall. Dalam hal ini dicontohkan ungkapan dari DA sebagai berikut:

"Selama ini (saya) tidak pernah mendapatkan sosialisasi mengenai pegadaian syariah".

Demikian juga yang disampaikan oleh IS sebagai berikut:

“(Saya) tidak pernah mendapatkan sosialisasi tentang PT Pegadaian Syariah".

Hal berbeda disampaikan oleh DK yang pernah mendapatkan sosialisasi dari PT Pegadaian Syariah sebagai berikut:

"Produk Rahn merupakan pembiayaan yang ditawarkan oleh pegadaian syariah kepada para nasabah yang membutuhkan dana cepat sesuai ketentuan syariah. produk Tabungan Emas adalah layanan penitipan saldo emas yang memudahkan masyarakat untuk dapat berinvestasi emas. Karena pada saat itu saya menggunakan produk tabungan emas, sehingga petugas pegadaian hanya memberikan penjelasan kepada saya mengenai tabungan emas yang saya buat. Penjelasan yang dilakukan oleh petugas kepada saya bahwa dengan memiliki tabungan emas, saya dapat menabung emas hanya dengan membayar 0,1 gram atau mencicil"'.

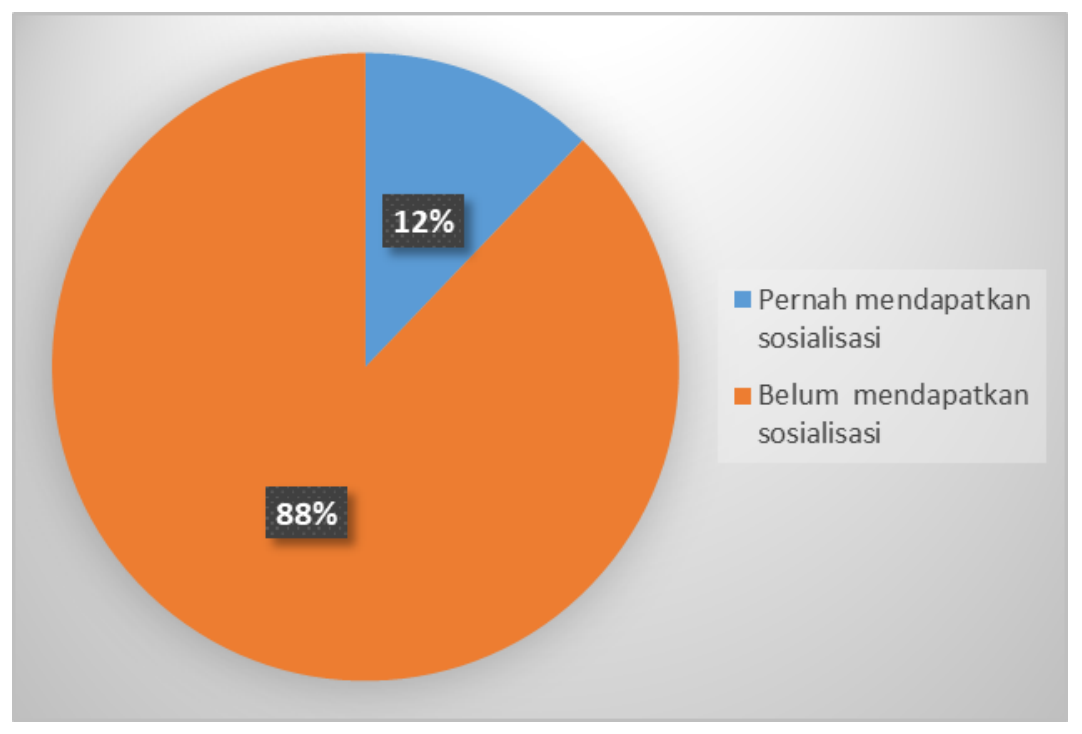

Berdasarkan data yang terkumpul ternyata sebesar 38 responden (51\%) menyatakan tidak berminat untuk memanfaatkan jasa LKS, meskipun telah menempuh mata kuliah Fiqih Muamalah dan melakukan survei pada LKS. Dengan kata lain, meskipun responden telah memahami pentingnya menyelenggarakan aktivitas muamalah syariah ternyata mereka

JAA belum merasa perlu menggunakan jasa LKS dengan beragam alasan. Sementara yang berminat memanfaatkan jasa LKS setelah mendapatkan pemahaman mengenai muamalah 4.1 syariah sebesar 36 responden (49\%), meskipun sebagian diantaranya menjawab tidak untuk saat ini. Dalam hal ini dapat dicontohkan pendapat dari DA sebagai berikut: 
"Faktor yang menyebabkan (saya) belum memanfaatkan jasa dari PT Pegadaian syariah yaitu faktor dari dalam diri, dorongan produk gadai, apakah saya membutuhkan jasa pegadaian syariah, produk gadai sesuai prinsip syariah. Dan faktor ekonomi juga yang berkecukupan sehingga tidak perlu gadai".

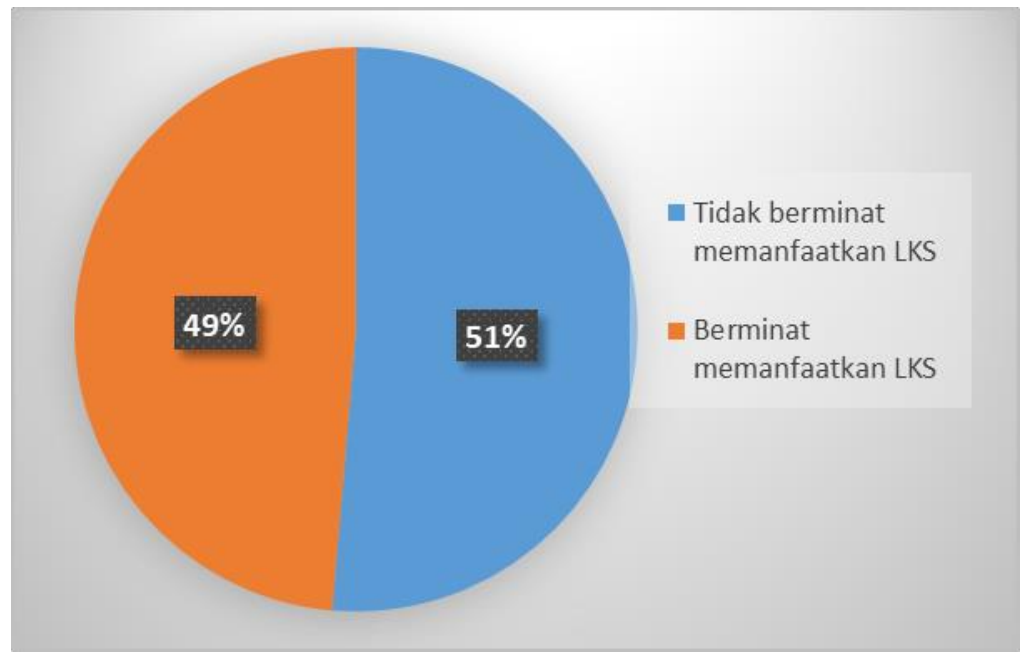

Responden yang berminat memanfaatkan jasa LKS sebagian besar berminat pada akad Rahn (48\%), sementara lainnya berminat pada akad Ijarah (24\%), Mudharabah (16\%), dan Arrum Haji (12\%).

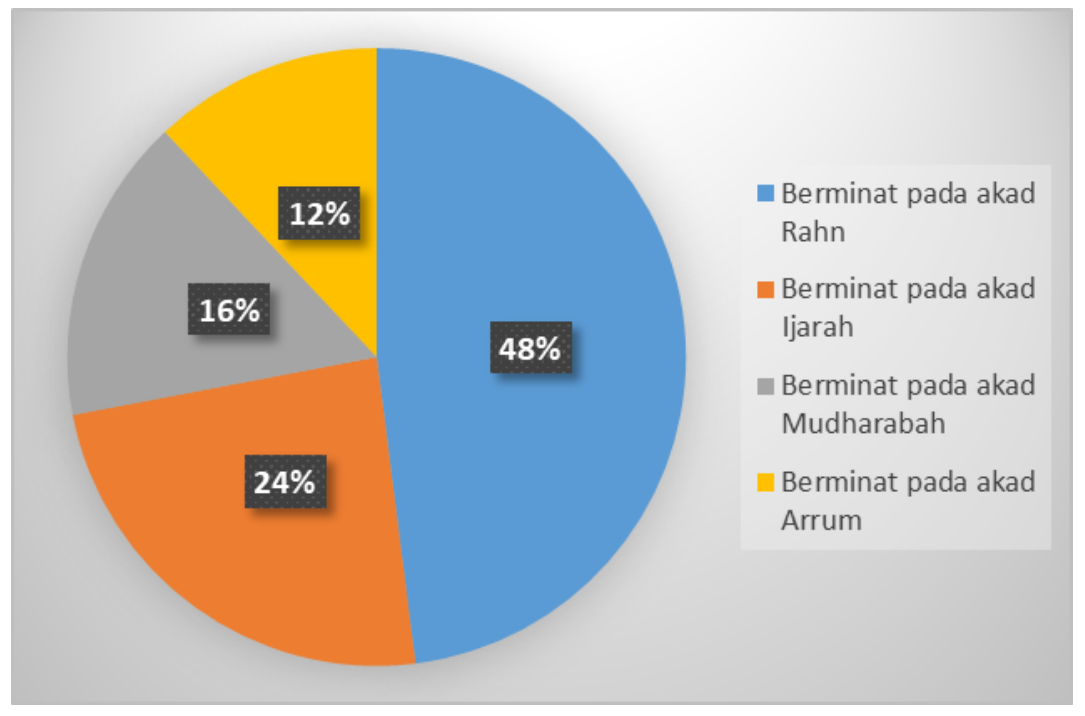

Hal yang perlu dicermati lebih lanjut adalah jawaban-jawaban yang disampaikan oleh Responden mengenai kesyariahan produk LKS mayoritas menjawab secara normatif. Sebagian besar Responden menyampaikan bahwa produk LKS Syariah pastilah Syar'i, sesuai dengan fatwa DSN MUI dan ketentuan OJK, tanpa perlu melakukan analisis yang seksama terhadap kesyariahan dari masing-masing produk LKS Syariah tersebut. Salah satunya diungkapkan oleh HS sebagai berikut:

"...Menurut saya pegadaian yang sudah berlebel syariah pastinya sudah mengikuti rukun syariah dan syarat yang tertera untuk pegadaian yang ingin menjadi pegadaian syariah.”

Dalam hal ini IA juga mengungkapkan sebagai berikut:

"...Menurut saya, tidak ada akad-akad yang mengandung hal-hal yang dilarang dalam perniagaan karena akad-akad tersebut sudah sesuai dalam ajaran agama islam. Karena, 
seperti yang kita tahu semua akad-akad terdapat dasar hukum seperti fatwa MUI dan sudah ditulis bahwa akad-akad tersebut sudah terlindungi tanpa ada unsur perniagaan didalamnya".

Ada juga pendapat yang agak berbeda dari DA, tetapi jawaban tetap bersifat normatif. Artinya Respoden tidak melakukan analisis yang mendalam terhadap produk LKS tersebut. Jawaban tersebut disampaikan oleh DA sebagai berikut:

“... Menurut saya memang harus terbebas dari hal hal yang dilarang karena jika tidak maka PT Pegadaian Syariah belum bisa disebut syariah..."

\section{SIMPULAN}

Berdasarkan hasil penelitian dapat disimpulkan sebagai berikut 1) Persepsi mahasiswa tentang produk Pegadaian Syariah adalah pasti sesuai dengan ketentuan syariah, yaitu ketentuan OJK dan fatwa DSN MUI, meskipun tidak melakukan kajian yang seksama terhadap penerapan masing-masing produk Pegadaian Syariah beserta akad dan rukunnya. 2) Sebagian besar responden bukan merupakan nasabah dari LKS dan tidak pernah mendapatkan sosialisasi terkait LKS dan produk-produk yang ditawarkan. 3) Setelah memahami pentingnya muamalah syariah, ternyata mayoritas belum berminat untuk memanfaatkan jasa LKS pada saat ini, karena merasa belum memerlukan. Berdasarkan hasil penelitian maka disarankan perlunya: 1) Sosialisasi yang lebih intensif dari pihak PT Pegadaian Syariah terhadap produk-produk yang ditawarkan dan tata cara untuk mengaksesnya. 2) Dalam perkuliahan Fiqih Muamalah perlu disajikan ilustrasi mengenai produk-produk LKS agar lebih dipahami oleh mahasiswa.

\section{DAFTAR PUSTAKA}

Anggraini, Tuti. 2015. Tingkat Pemahaman (Awareness) Nasabah terhadap Perbankan Syariah. Bunga Rampai LKS dan Dinamika Sosial. FEBI UIN-SU Press. Medan.

Dimyati, M. 2000. Penelitian Kualitatif: Paradigma Epistemologi, Pendekatan, Metode, dan Terapan. PPS Universitas Negeri Malang. Malang.

Mensani, RD dan A Dzikra. 2017. Islam dan Lembaga Keuangan Syariah. AL-INTAJ, Vol. 3 No. 1, Maret 2017. Fakultas Ekonomi dan Bisnis Islam. UIN Padang, Sumbar.

Moleong, L. J. 1991. Metodologi Penelitian Kualitatif. Remaja Rosdakarya. Bandung.

Sarwat, A. 2013. Fiqih Muamalat. E-Book.

Tim DSN MUI Institute. 2018. Mengenal Dewan Syariah Nasional Majelis Ulama Indonesia (DSN-MUI) dan DPS (Dewan Pengawas Syariah). modul Pelatihan Koperasi Syariah. Tim DSN-MUI.

Waters, Malcolm. 1994. Modern Sociological Theory. Sage Publications. London.

Wirawan, Ida B. 2012. Teori-Teori Sosial dalam Tiga Paradigma Fakta Sosial, Definisi Sosial, \& Perilaku Sosial. Kencana Prenada Media Group. Jakarta 